AGRARIS: Journal of Agribusiness and Rural Develpoment Research

Vol. 4 No. 2 Juli-Desember 2018
Mohammad Rondhi ${ }^{*}$, Ad Hariyanto Adi

Department of Agribusiness, University of Jember

*) e-mail korespondensi: rondhi.faperta@unej.ac.id

\section{Pengaruh Pola Pemilikan Lahan Terhadap Produksi, Alokasi Tenaga Kerja, dan Efisiensi Usahatani Padi}

\author{
The Effects of Land Ownership on Production, \\ Labor Allocation, and Rice Farming Efficiency
}

DOI: http://dx.doi.org/10.18196/agr.4265 contract farming between farmer and landlord was the best economic choice for the landlord. Furthermore, to improve farmers welfare, the landless farmers should be facilitated to own their own land.

Keywords: farmer welfare, informal contract farming, kedokan, land ownership,

\section{INTISARI}

Lahan adalah input utama dalam produksi pertanian dan juga aset produktif bagi petani. Terdapat tiga pola pemilikan lahan pertanian: Iahan milik sendiri, sewa, dan bagi hasil, dimana masing-masing pola secara langsung mempengaruhi kinerja usahatani. Tujuan peneliatian ini adalah menganalisis pengaruh pola pemilikan lahan pada produksi, alokasi tenaga kerja, dan efisiensi ekonomi usahatani. Jumlah sampel yang digunakan adalah 150 petani yang tersebar merata pada tiap pola pemilikan lahan dari populasi sebanyak 1039 petani. Fungsi produksi Cobb-Douglas, Uji-F, dan RC ratio digunakan untuk mengestimasi fungsi produksi, perbedaan alokasi tenaga kerja, dan efisiensi ekonomi usahatani. Hasil penelitian ini menunjukkan bahwa lahan sewa memiliki produktivitas tertinggi, diikuti lahan milik, dan lahan bagi hasil. Sementara itu lahan bagi hasil memiliki penggunaan tenaga kerja paling rendah, diikuti lahan sewa dan lahan milik. Akan tetapi dalam hal profitabilitas, lahan milik sendiri memiliki profitabilitas tertinggi, diikuti lahan sewa dan lahan bagi hasil. Hasil penelitian juga menunjukkan bahwa kedokan sebagai bentuk kemitraan usahatani informal antara petani/pengedok dan pemilik lahan adalah pilihan ekonomi terbaik bagi pemilik lahan. Penelitian ini menyarankan bahwa dalam usaha meningkatkan kesejahteraannya, petani perlu difasilitasi untuk memiliki lahannya sendiri.

Kata kunci: kemitraan usahatani informal, kesejahteraan petani, pola pemilikan lahan, sistem bagi hasil kedokan

\section{PENDAHULUAN}

Berdasarkan pola pemilikannya, lahan usahatani dibagi menjadi tiga jenis yakni lahan milik sendiri, lahan sewa, dan lahan bagi hasil (Hayami \& Otsuka, 1993). Persentase masing-masing jenis lahan di beberapa negara Asia pada tahun 1970yakni 84\% lahan milik sendiri, 5,9\% lahan sewa, dan 10,1\% lahan bagi hasil. Angka tersebut 
menunjukkan bahwa ketiga pola pemilikan lahan tersebut telah diterapkan secara luas dan bertahan cukup lama di Asia, termasuk di Indonesia. Lebih jauh lagi, perbedaan pemilikan lahan secara signifikan mempengaruhi efisiensi dan pendapatan usahatani (Koirala, Mishra, \& Mohanty, 2016; Mubyarto, 2006). Oleh karena itu pembahasan mengenai pola pengelolaan lahan ini penting dalam usaha mencapai ketahanan pangan dan kesejahteraan petani.

Secara umum pola lahan milik sendiri dan sewa cenderung sama di berbagai wilayah di Indonesia, tetapi perbedaan yang cukup signifikan terjadi pada pola pengelolaan lahan bagi hasil. Pola lahan bagi hasil memiliki nama dan aturan tersendiri pada berbagai wilayah, seperti maro di Jawa Tengah (Wahyuningsih, 2010); maro, mertelu, mrapat, dan kedokan di Jawa Timur (Malik, Wahyuni, \& Widodo, 2018); nengah atau jejuron dan ceblokan di Jawa Barat (Sihaloho, Purwandari, \& Mardiyaningsih, 2010); memperduai di Sumatera Barat, toyo di Minahasa, serta teseng di Sulawesi Selatan (Darwis, 2016). Perbedaan aturan masing-masing sistem bagi hasil berhubungan dengan proporsi bagi hasil dan juga kewajiban dan hak dari petani pemilik dan petani penggarap. Seperti contoh pada sistem maro di Kabupaten Sleman dimana proporsi bagi hasil antara pemilik lahan dan petani penggarap adalah 50\%:50\% dan petani penggarap menanggung seluruh input produksi, alat pertanian, dan risiko gagal panen sementara pemilik lahan berkewajiban menyediakan lahan serta membayar pajak lahan (Ash Shidiqie \& Priyadi, 2015). Sementara pada sistem sakap (istilah lain maro) di Jawa Barat petani pemilik lahan juga berkewajiban untuk membiayai setengah biaya bibit dan proporsi bagi hasil sama dengan sistem maro sebelumnya (Hadiana, 2017). Perbedaan proporsi bagi hasil serta aturan pembagian hak dan kewajiban akan mempengaruhi kinerja petani penggarap yang pada ahirnya akan mempengaruhi kinerja usahatani. Lebih jauh lagi, perbedaan struktur usahatani petani pemilik (farmer), petani penggarap lahan sewa (tenant farmer), dan petani penggarap lahan bagi hasil (sharecropper) juga akan membuat kinerja masing-masing petani berbeda.

Pengaruh pola pemilikan lahantelah banyak diteliti dan menunjukkan bahwa masih terdapat perbedaan. Pada usahatani padi di Kabupaten Minahasa Selatan, pendapatan tertinggi dimiliki petani penyewa, sementara petani penggarap memiliki pendapatan terendah (Manatar, Laoh, \& Mandei, 2017). Sementara di Kabupaten Buru, kinerja petani pemilik dan penyewa relatif sama akan tetapi berbeda dengan petani penyakap (bagi hasil) dimana kinerja petani penyakap lebih rendah (Bahasoan, 2011). Berbeda dari dua penelitian sebelumnya, pada usahatani padi di Kabupaten Kendal, produktivitas petani pemilik, penyakap, dan penyewa tidak berbeda cukup signifikan (Mudakir, 2011). Hasil tersebut menunjukkan bahwa masih terdapat perbedaan pendapat terkait pengaruh pola pemilikan lahan terhadap kinerja usahatani. Sehingga penelitian ini berusaha untuk berkontribusi pada pembahasan tersebut.

Sistem kedokan adalah sistem yang relatif jarang dibahas pada penelitian sebelumnya secara rinci. Pada sistem kedokan yang terjadi pada komoditas padi di Kabupaten Jember, pengedok (petani penggarap) hanya berkewajiban sebagai penyedia tenaga kerja panen dan mendapatkan 20\% gabah yang diproduksi (Fauzi, Hariyati, \& Aji, 2014). Sementara itu, sistem kedokan di Kabupaten Lumajang memiliki pola yang sedikit berbeda, pengedok berkewajiban menyediakan biaya benih, pupuk, sewa traktor dan biaya irigasi dengan proporsi bagi hasil yang berbeda tergantung dari kondisi usahatani (Malik et al., 2018)

Pelaksanaan sistem kedokan mempunyai banyak keragaman, sehingga penelitian sistem kedokan di Desa Jatimulyo, Kecamatan Jenggawah, Kabupaten Jember memberikan informasi baru tentang sistem kedokan dimana pengedok hanya berkewajiban untuk melakukan perawatan padi. Selain itu, penelitian ini juga menguraikan alokasi tenaga kerja pada masing-masing pola pemilikan lahan. Pembahasan ini jarang dilakukan pada penelitian sebelumnya. Alokasi tenaga kerja usahatani penting untuk dibahas karena $48,23 \%$ total biaya usahatani digunakan untuk ongkos tenaga kerja (Badan Pusat Statistik, 2015). Secara spesifik, penelitian ini bertujuan untuk mengetahui pengaruh pola pemilikan lahan terhadap produksi usahatani padi; alokasi tenaga kerja usahatani pada masingmasing pola pemilikan lahan; dan efisiensi usahatani padi pada masing-masing pola pemilikan lahan.

\section{METODE PENELITIAN}

Penelitian ini dilaksanakan di Desa Jatimulyo, Kecamatan Jenggawah Kabupaten Jember, Jawa Timur. Desa Jatimulyo secara umum menggambarkan kondisi umum wilayah perdesaan di Indonesia yang dicirikan dengan perekonomian utamanya adalah pertanian tanaman pangan khususnya padi. Desa 
Jatimulyo terletak di Kecamatan Jenggawah dan merupakan bagian dari wilayah lumbung padi di Kabupaten Jember. Berdasarkan pola pemilikan lahan, petani padi di Desa Jatimulyo dibagi menjadi tiga yakni petani pemilik, petani penyewa, dan petani pengedok. Pengambilan sampel penelitian dilakukan dalam tiga tahap yakni, penentuan populasi penelitian, pengukuran jumlah sampel, dan penentuan petani responden. Populasi penelitian adalah seluruh petani padi yang ada di Desa Jatimulyo.

Penentuan populasi dilakukan dengan mengidentifikasi identitas petani yang mencakup nama, luas lahan, dan pola pemilikan lahan. Secara teknis penyusunan data populasi dilakukan dengan melakukan wawancara pada ulu-ulu. Pemilihan uluulu dalam penyusunan data populasi karena ulu-ulu mengetahui secara rinci setiap petani yang menjadi anggota di wilayah kerjanya. Selain itu, wilayah kerja HIPPA berbasis desa sehingga petani anggota hanya petani yang sawahnya terdaftar secara administratif di Desa Jatimulyo. Terdapat 15 ulu-ulu yang diwawancarai yang membawahi 1039 petani yang dirangkum pada Tabel 1.

\section{TABEL 1. POPULASI PETANI PADI DI DESA JATIMULYO BERDASARKAN POLA PEMILIKAN LAHAN}

\begin{tabular}{lcc}
\hline Pengelolaan Lahan & Jumlah Populasi (petani) & Persentase (\%) \\
\hline Miliksendiri & 798 & 76,80 \\
Sewa & 131 & 12,60 \\
Kedokan & 110 & 10,60 \\
\hline \multicolumn{1}{c}{ Total } & $\mathbf{1 0 3 9}$ & $\mathbf{1 0 0}$ \\
\hline
\end{tabular}

Sumber: Data Primer (2018)

Selanjutnya pengukuran jumlah sampel dilakukan dengan menggunakan rumus slovin dengan tingkat kesalahan sebesar 7,5 persen. Berdasarkan hasil perhitungan diperoleh jumlah sampel sebesar 150 petani. Selanjutnya, dikarenakan subpopulasi (petani pemilik, penyewa, dan pengedok) bersifat homogen, alokasi sampel untuk tiap sub populasi ditetapkan 50 petani pemilik, 50 petani penyewa, dan 50 petani pemilik lahan kedokan.

Pengumpulan data penelitian dilakukan dengan menggunakan metode wawancara terstruktur menggunakan kuesioner. Data yang dikumpulkan terkait dengan gambaran umum usahatani; faktor produksi yang meliputi luas lahan, jumlah serta jenis benih yang digunakan, jumlah dan jenispupuk yang digunakan, jumlah dan jenis pestisida yang digunakan dan jumlah tenaga kerja pada setiap kegiatan usahatani; serta biaya yang dikeluarkan dalam usahatani antara lain biaya pajak atau sewa lahan, biaya benih, biaya pupuk, biaya pestisida dan biaya tenaga kerja.Satuan luas lahan di lokasi penelitian menggunakan ukuran sepripit, seperempat dan sebahu yang kemudian ukuran luas lahan tersebut dikonversikan menjadi satuan hektar.

Statistik deskriptif beberapa variabel penelitian terpilih dari data penelitian yang telah dikumpulkan dirangkum pada Tabel 2.

\section{TABEL 2. STATISTIK DESKRIPTIF DATA PENELITIAN}

\begin{tabular}{cccc}
\hline Variabel & Pemilik & Penyewa & Pengedok \\
\hline Luas Lahan $(\mathrm{ha})^{*}$ & $0,3(0,22)$ & $0,36(0,42)$ & $0,44(0,27)$
\end{tabular}

Biaya Benih (Rp) ${ }^{\star *} \quad 155.420(8,4) \quad 182.920(4,6) \quad 200.460$

(9,5)

Biaya Pupuk (Rp) ${ }^{\star *} \quad 406.380 \quad 423.250 \quad 503.320$

$(22,1) \quad(10,7) \quad(24)$

Biaya Pestisida (Rp) ${ }^{* *} \quad 43.610(2,3) \quad 36.620(0,9) \quad 37.200(1,7)$

$\begin{array}{llll}\text { Biaya Tenaga Kerja } \quad 581.600 & 753.800 \quad 545.684\end{array}$

$(\mathrm{Rp})^{* *}$

$(31,9) \quad(19,1) \quad(26)$

Biaya Sewa Mesin $\quad 586.504 \quad 734.196$ '31.382 $(34,9)$

Pertanian $(\mathrm{Rp})^{* *}$

$(31,9) \quad(18,6)$

Biaya Sewa Lahan

$0 \quad 1.783 .470(45$,

$(\mathrm{Rp})^{\star \star}$

Jumlah Observasi

50

2)

Sumber: Data Primer (2018)

* angka dalam kurung menunjukkan simpangan baku

** angka dalam kurung menunjukkan persentase dari total biaya

Data pada Tabel 2 menunjukkan adanya kesesuaian antara data di lokasi penelitian dengan gambaran umum usahatani padi di Indonesia Struktur biaya usahatani padi sawah di Indonesia menunjukkan bahwa biaya usahatani terbesar adalah biaya tenaga kerja dan sewa mesin pertanian (Badan Pusat Statistik, 2015). Secara spesifik terdapat perbedaan dalam penguasaan lahan dimana petani pemilik mengusahakan lahan paling sempit, diikuti dengan penyewa, dan yang terluas adalah petani pengedok. Luasan tersebut adalah rata-rata luasan lahan yang dimiliki oleh pemilik lahan yang memilih untuk mengedokkan lahannya.

Pengaruh pola pemilikan lahan terhadap produksi dianalisis dengan menggunakan fungsi 
produksi Cobb-Douglas. Variabel yang digunakan dalam model regresi tercantum padaTabel 3. Variabel yang digunakan dalam model terdiri dari variabel jenis input usahatani dan pola pemilikan lahan. Variabel input usahatani mencakup luas lahan (X1), jumlah benih (X2), jumlah pupuk urea(X3), jumlah pupuk $\mathrm{Za}(\mathrm{X} 4)$, jumlah pupuk phonska(X5), jumlah pestisida(X6), dan jumlah tenaga keja(X7). Tenaga kerja usahatani tidak dibedakan berdasarkan gender karena upah yang dibayarkan kepada tenaga kerja pria dan wanita memiliki nilai sama. Variabel terahir adalah variabel dummy pemilikan lahan yang terdiri dari lahan sewa (D1), dan lahan bagi hasil kedokan (D2).

Model fungsi produksi Cobb-Douglas (Persamaan 1) diestimasi menggunakan metode ordinary least square dan digunakan untuk mengetahui perbedaan produksi pada masing-masing pola pemilikan lahan.

$$
Y=a X_{1}^{b_{1}} X_{2}^{b_{2}} X_{3}^{b_{3}} X_{4}^{b_{4}} X_{5}^{b_{5}} X_{6}^{b_{6}} X_{7}^{b_{7}} D^{b_{8}}
$$

Model tersebut ditransformasikan dalam bentuk double logaritme natural (ln) untuk memudahkan proses estimasi. Hasil transformasi ditunjukkan pada Persamaan 2.

$$
Y=a+\sum_{i=1}^{7} b_{i} \ln X_{i}+b_{8} D
$$

Data penelitian memiliki variabel yang bernilai nol, seperti pupuk $\mathrm{Za}$, ada petani tidak menggunakan pupuk tersebut sehingga data pupuk $\mathrm{Za}$ untuk petani tersebut bernilai nol. Nilai 0 pada salah satu data akan menjadi masalah dalam proses estimasi fungsi produksi Cobb-Douglas karena ketika dilakukan transformasi logaritma variabel dengan nilai 0 akan menjadi tak hingga. Solusi dari permasalahan ini adalah dengan melakukan estimasi dua tahap. Estimasi pertama menggunakan data asli sementara estimasi kedua menggunakan data yang sudah ditransformasi dengan menambahkan angka yang sama pada setiap variabel. Berdasarkan hasil estimasi dua tahap diperoleh hasil yang tidak berbeda secara statistik, sehingga hasil estimasi yang dimuat adalah hasil estimasi data asli. Uji statistik yang dilakukan untuk mengetahui kelayakan model adalah Uji F dan Uji t (Setiawan \& Kusrini, 2010)
Alokasi tenaga kerja pada masing-masing pola pemilikan lahan dibagi berdasarkan jenis tenaga kerja (dalam keluarga dan luar keluarga) dan tahapan usahatani yakni pembersihan lahan, pengolahan tanah, persemaian benih, pembuatan bedengan, pencabutan bibit, penanaman, penyiangan, pemupukan, penyemprotan, dan panen. Selanjutnya untuk mengetahui untuk mengetahui apakah terdapat perbedaan alokasi tenaga kerja pada usahatani petani pemilik, penyewa, dan pengedok dilakukan uji anova(Setiawan \& Kusrini, 2010). Sementara efisiensi usahatani masing-masing pola pemilikan lahan dianalisis menggunakan metode $\mathrm{RC}$ ratio(Soekartawi, 1995). Terdapat dua nilai RC ratioyang akan dihitung yakni RC ratio dengan memperhitungkan biaya implisit dan tanpa memperhitungkan biaya implisit tenaga kerja dalam keluarga(Soekartawi, 1995).

\section{HASIL DAN PEMBAHASAN}

\section{MEKANISME PELAKSANAAN POLA BAGI HASIL KEDOKAN}

Sistem kedokan adalah bentuk kemitraan informal antara pemilik lahan dan petani penggarap atau pengedok. Seperti kemitraan pada umumnya terdapat pembagian hak dan kewajiban dari masingmasing pihak yang menjalin kemitraan. Tabel 4 merangkum hak dan kewajiban pemilik lahan dan pengedok dalam sistem bagi hasil kedokan.

TABEL 3 PEMBAGIAN HAK DAN KEWAJIBAN DALAM SISTEM BAGI HASIL KEDOKAN

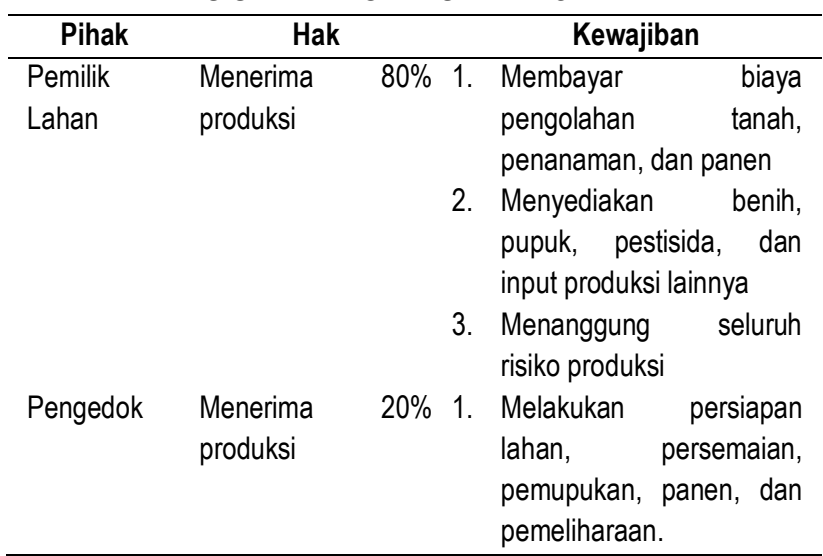

Sistem kedokan merupakan sistem kerjasama revenue sharing dimana pengedok memperoleh 
seperlima hasil produksi sementara sisanya menjadi hak pemilik lahan. Proporsi bagi hasil sesuai dengan kewajiban yang harus dipenuhi oleh masing-masing pihak. Pemilik lahan menyediakan seluruh input produksi serta tenaga kerja untuk pengolahan tanah (sewa traktor), penanaman, dan panen. Sementara pengedok menyediakan tenaga untuk persiapan lahan, persemaian (pembuatan uritan), pemupukan, panen, dan pemeliharaan.

Pembagian hak dan kewajiban dalam sistem kedokan sesuai dengan karakteristik dasar masingmasing pihak. Pemilik lahan pada umumnya adalah masyarakat ekonomi memengah akan tetapi tidak memiliki waktu untuk mengelola lahannya sendiri. Sehingga pemilik lahan selain menyediakan lahan juga menyediakan seluruh input dan juga tenaga kerja luar keluarga selain pengedok. Selain itu pemilik lahan juga menanggung seluruh risiko produksi dimana ketika terjadi kegagalan panen maka kerugian seluruhnya ditanggung pemilik lahan. Sementara pengedok berkewajiban melakukan persiapan lahan, persemaian, perawatan, dan panen. Semua tugas tersebut dilaksanakan sendiri oleh pengedok. Keuntungan bagi pengedok adalah tidak menanggung risiko produksi sama sekali. Berbeda dengan sistem bagi hasil lainnya seperti maro dan sakap dimana penggarap masih harus menyediakan sebagian input produksi dan menanggung sebagian risiko produksi.

\section{PENGARUH POLA PEMILIKAN LAHAN TERHADAP PRODUKSI USAHATANI}

Pengaruh pola pemilikan lahan terhadap produksi diestimasi menggunakan fungsi produksi Cobb-Douglas. Uji F digunakan untuk melihat apakah seluruh variabel independen berpengaruh terhadap produksi usahatani (HO :seluruh koefisien variabel independen bernilai 0). Nilai F statistik model yang diestimasi adalah 137,313 dan lebih besar dibandingkan nilai $F$ tabel 1,95 ( $p<0,05 ; p=0,000)$. Hasil tersebut menunjukkan bahwa seluruh variabel independen berpengaruh nyata terhadap produksi usahatani (H0 ditolak). Kemudian nilai R2 adalah 0,892 yang artinya 89,2 persen varian produksi bisa dijelaskan oleh variabel independen dalam model. Nilai tersebut baik karena data yang digunakan terbebas dari permasalahan multikolinearitas, normalitas, dan heteroskedastisitas. Berdasarkan hasil tersebut model yang diestimasi layak digunakan untuk menjelaskan pengaruh pola pemilikan lahan pada produksi.Hasil estimasi ditunjukkan pada Tabel 4.

TABEL 4 HASIL ESTIMASI FUNGSI PRODUKSI COBBDOUGLAS

\begin{tabular}{lcc}
\hline \multicolumn{1}{c}{ Variabel } & Koefisien & t hitung (signifikansi) \\
\hline Konstanta & $-1,030$ & $-4,493(0,000)^{*}$ \\
Luas Lahan & 0,284 & $7,812(0,000)^{*}$ \\
Benih & 0,467 & $8,484(0,000)^{*}$ \\
Pupuk Urea & 0,037 & $1,849(0,067)^{* * *}$ \\
Pupuk ZA & 0,007 & $0,679(0,499)^{\text {ns }}$ \\
Pupuk Phonska & 0,008 & $0,643(0,521)^{\text {ns }}$ \\
Pestisida & 0,028 & $-1,589(0,114)^{\text {ns }}$ \\
Tenaga Kerja & 0,120 & $1,893(0,060)^{* * *}$ \\
Dummy sewa & 0,123 & $3,042(0,003)^{* *}$ \\
Dummy kedokan & $-0,061$ & $-1,049(0,146)^{\text {ns }}$ \\
$R^{2}$ & 0,892 & \\
F hitung & 137,313 \\
\hline Keterangan, ${ }^{* * *}=p<0,01,{ }^{* *}=p<0,05,{ }^{*}=p<0,1, n s:$ tidak signifikan
\end{tabular}

Berdasarkan hasil esimasi didapatkan bahwa bibit, tenaga kerja, dan luas lahan merupakan faktor produksi yang memiliki pengaruh positif besar terhadap produksi karena memiliki koefisien produksi sebesar 0,467;0,284; dan 0,120. Nilai tersebut jauh lebih besar dibandingkan dengan faktor produksi lain seperti pupuk dan pestisida. Pupuk-baik urea, ZA, dan phonska-memiliki pengaruh positif akan tetapi tidak terlalu besar, besar koefisien regresi ketiga jenis pupuk tersebut adalah 0,037; 0,008; dan 0,007. Artinya, produksi usahatani padi di Desa Jatimulyo tidak terlalu bergantung pada penggunaan pupuk. Penambahan jumlah pupuk yang digunakan hanya meningkatkan produksi dalam jumlah yang relatif kecil. Sementara itu, pestisida memiliki pengaruh negatif akan tetapi relatif kecil terhadap produksi dengan koefisien regresi sebesar -0,028. Kondisi produksipadi di Desa Jatimulyo yang tidak bergantung pada penggunaan pupuk ini juga terjadi pada usahatani padi di Provinsi Lampung (Asnawi, 2013) di Desa Kirisik, Kecamatan Jatinunggal, Kabupaten Sumedang (Hadiana, 2017), di Kabupaten Kendal (Mudakir, 2011), di Desa Haekto, Kecamatan Neomuti Timur, Kabupaten Timor Tengah Selatan 
(Neonbota \& Kune, 2016), di Kelurahan Koya, Kecamatan Tondano Selatan, Kabupaten Minahasa (Onibala, Sondakh, Kaunang, \& Mandei, 2017), di Desa Lawang Agung, Kecamatan Kedurang, Kabupaten Bengkulu Selatan (Sumantri \& Fauzi, 2006), dan di Kecamatan Wirosari, Kabupaten Grobogan (Yuliana, Ekowati, \& Handayani, 2017). Berbagai penelitian ini menunjukkan bahwa usahatani padi di Indonesia merupakan struktur produksi yang berbasis lahan dan tenaga kerja.

Selanjutnya pengaruh pola pemilikan lahan pada produksi dapat diketahui dari nilai konstanta, dummy sewa, dan dummy kedokan. Nilai konstanta mewakili pola lahan milik sendiri dengan nilai $-1,030$ dan signifikan secara statistik, koefisien dummy sewa memiliki nilai 0,123 dan signifikan secara statistik. Artinya lahan sewa memiliki produksi yang lebih baik dibandingkan dengan pola milik sendiri. Selanjutnya lahan kedokan secara statistik tidak berpengaruh signifikan pada produksi dan juga memiliki koefisien negatif, sehingga pola kedokan tidak lebih baik dibandingkan dengan pola milik sendiri dan sewa.Kondisi tersebut sejalan dengan pola pemilikan lahan usahatani padi di Kabupaten Buru dimana usahatani padi pada pola lahan sewa memiliki nilai produksi tertinggi, diikuti dengan pola lahan milik, dan pola lahan sakap (bagi hasil) memiliki koefisien negatif (Bahasoan, 2011). Sementara itu, kondisi lahan sewa di Desa Jatimulyo memiliki kesamaan dengan dengan usahatani di Desa Tumani, Kecamatan Maesaan, Kabupaten Minahasa yang memiliki produksi tertinggi, akan tetapi produksi terendah tidak terjadi pada lahan bagi hasil melainkan pada lahan milik sendiri (Manatar et al., 2017).

\section{ALOKASI TENAGA KERJA USAHATANI PADA MASING-MASING POLA PEMILIKAN LAHAN}

Terdapat sepuluh pos alokasi tenaga kerja dalam usahatani padi yakni persiapan lahan, pengolahan tanah, persemaian benih, pembuatan bedengan, pencabutan bibit, penanaman bibit, penyiangan, pemupukan, penyemprotan obat, dan panen. Terdapat dua jenis tenaga kerja yang digunakan dalam usahatani padi yang diteliti yakni tenaga kerja dalam keluarga (TKDK) dan tenaga kerja luar keluarga (TKLK). Tabel 5 merangkum alokasi tenaga kerja pada masing-masing pola pemilikan lahan. Satuan yang digunakan adalah hari orang kerja (HOK)/hektar.

TABEL 5 ALOKASI TENAGA KERJA USAHATANI PADI BERDASARKAN POLA PEMILIKAN LAHAN

\begin{tabular}{|c|c|c|c|c|c|c|}
\hline \multirow{2}{*}{$\begin{array}{l}\text { Pengelolaan } \\
\text { Lahan }\end{array}$} & \multicolumn{2}{|c|}{ Milik Sendiri } & \multicolumn{2}{|c|}{ Sewa } & \multicolumn{2}{|c|}{ Kedokan } \\
\hline & TKDK & TKLK & TKDK & TKLK & TKDK & TKLK \\
\hline $\begin{array}{l}\text { Pembersihan } \\
\text { Lahan }\end{array}$ & 0,603125 & 0,525 & 0,8675 & 0,5225 & 0,0575 & 1,055 \\
\hline $\begin{array}{l}\text { Pengolahan } \\
\text { Tanah }\end{array}$ & 0 & 0,81 & 0 & 1,735 & 0 & 1,165 \\
\hline $\begin{array}{l}\text { Persemaian } \\
\text { Benih }\end{array}$ & 0,234375 & 0,18 & 0,2575 & 0,15 & 0,005 & 0,44 \\
\hline $\begin{array}{l}\text { Pembuatan } \\
\text { Bedengan }\end{array}$ & 0,46875 & 0,23 & 0,46 & 0,2875 & 0,075 & 0,875 \\
\hline $\begin{array}{l}\text { Pencabutan } \\
\text { Bibit }\end{array}$ & 0,25 & 0,5575 & 0,095 & 0,6525 & 0,1775 & 1,0675 \\
\hline Penanaman & 0 & 7,91 & 0 & 9,7275 & 0 & 11,0275 \\
\hline Penyiangan & 0,80625 & 0,2425 & 1,1375 & 0,5425 & 0,225 & 1,6 \\
\hline Pemupukan & 1,5 & 0,3975 & 1,2825 & 0,705 & 0,1575 & 2,295 \\
\hline Penyemprotan & 0,4 & 0,165 & 0,5125 & 0,1525 & 0 & 1,225 \\
\hline Panen & 0 & 3,5225 & 0 & 4,37 & 0 & 4,4575 \\
\hline $\begin{array}{l}\text { Rata-rata Total } \\
\text { HOK/Luasan }\end{array}$ & 4,2625 & 14,54 & 4,6125 & 18,845 & 0,6975 & 25,2075 \\
\hline $\begin{array}{l}\text { Rata-rata Total } \\
\text { HOK/Hektar }\end{array}$ & 37,3573 & 75,8573 & 23,172 & 81,669 & 1,5820 & 68,8268 \\
\hline
\end{tabular}

Rata-rata total tenaga kerja untuk lahan milik sendiri, sewa dan kedokan adalah 113,21 HOK, 104,84 HOK, dan 70,408 HOK. Penggunaan tenaga kerja pada masing-masing pola pemilikan lahan juga berbeda secara statistik dengan signifikansi uji ANOVA sebesar 0,659. Penggunaan tenaga kerja terbesar terdapat pada kegiatan penanaman dan panen. Kedua kegiatan ini membutuhkan tenaga kerja dalam jumlah yang banyak karena penanaman dan panen harus diselesaikan dalam waktu satu hari. Sehingga, penggunaan tenaga kerja luar keluarga pada kedua kegiatan tersebut sangat besar. Sebaliknya kegiatan perawatan usahatani membutuhkan tenaga kerja luar keluarga lebih sedikit karena bisa dilakukan oleh petani sendiri. Data tersebut menunjukkan bahwa petani pengedok (contract labor) merupakan tenaga kerja pengganti tenaga kerja keluarga (family labor), sementara buruh tani (hired labor) adalah tenaga kerja komplementer bagi tenaga kerja keluarga, hubungan ini juga telah teridentifikasi pada struktur tenaga kerja pertanian di Prancis (Dupraz \& Latruffe, 2015)

Selanjutnya, akan dibandingkan jumlah tenaga kerja yang menjadi tanggungan pengedok, petani sewa, dan 
petani milik sendiri. Terlebih dahulu perlu dilakukan pemisahan antara tenaga kerja yang menjadi tanggungan pemilik lahan kedokan dan juga pengedok. Kemudian, alokasi tenaga kerja petani pengedok dibandingkan dengan alokasi tenaga kerja petani sewa dan milik sendiri. Tabel 6 merangkum jumlah tenaga kerja yang menjadi tanggungan petani pengedok, pemilik lahan kedokan, petani sewa, dan petani milik sendiri.

TABEL 6 PERBANDINGAN ALOKASI TENAGA KERJA TIAP PETANI (HOK/MUSIM)

\begin{tabular}{|c|c|c|c|c|}
\hline \multirow{2}{*}{$\begin{array}{l}\text { Kegiatan } \\
\text { Usahatani }\end{array}$} & \multicolumn{2}{|c|}{ Kedokan } & \multirow{2}{*}{$\begin{array}{l}\text { Petani } \\
\text { sewa }\end{array}$} & \multirow{2}{*}{$\begin{array}{l}\text { Petani } \\
\text { milik } \\
\text { sendiri }\end{array}$} \\
\hline & $\begin{array}{l}\text { Pemilik } \\
\text { lahan }\end{array}$ & $\begin{array}{l}\text { Penge- } \\
\text { dok }\end{array}$ & & \\
\hline Pembersihan Lahan & 0 & 3,1539 & 6,1528 & 8,209696 \\
\hline Pengolahan Tanah & 3,1787 & 0 & 0 & 0 \\
\hline Persemaian Benih & 0 & 1,23685 & 1,9 & 3,22729 \\
\hline $\begin{array}{l}\text { Pembuatan } \\
\text { Bedengan }\end{array}$ & 2,44067 & 0 & 0 & 0 \\
\hline Pencabutan Bibit & 0 & 3,02078 & 3,319 & 4,870801 \\
\hline Penanaman Bibit & 29,3752 & 0 & 0 & 0 \\
\hline Penyiangan & 0 & 4,75308 & 6,84 & 7,949813 \\
\hline Pemupukan & 0 & 6,940385 & 11 & 13,73953 \\
\hline Penyemprotan Obat & 0 & 3,41436 & 3,59 & 2,578979 \\
\hline Panen & 0 & 12,5182 & 18,5 & 20,60296 \\
\hline Jumlah & 34,9946 & 35,03755 & 51,302 & 61,1791 \\
\hline Rata-Rata & 11,6649 & 5,005365 & 7,3288 & 8,73987 \\
\hline
\end{tabular}

Jumlah tenaga kerja pada sistem kedokan yang menjadi tanggungan pemilik lahan sebesar 34,994 HOK/ha sedangkan yang menjadi tanggungan pengedok (untuk kegiatan perawatan) sebesar 35,038 $\mathrm{HOK} /$ ha. Sementara, curahan tenaga kerja dalam perawatan pada pola sewa sebesar 51,371 $\mathrm{HOK} /$ ha dan pada pola milik sendiri sebesar $61,179 \mathrm{HOK} / \mathrm{ha}$. Nilai tersebut menunjukkan bahwa penggunaan tenaga kerja dalam pola sewa dan milik sediri lebih besar dibandingkan dengan penggunaan tenaga kerja pada pola kedokan, khususnya penggunaan tenaga kerja pengedok. Kondisi tersebut menunjukkan bahwa nilai marginal produk tenaga kerja pada model sewa dan garap sendiri lebih besar dibandingkan dengan nilai marginal produk tenaga kerja pada model kedokan (pengedok). Rendahnya nilai marginal produk tenaga kerja pengedok disebabkan karena pengedok tidak akan mendapatkan insentif untuk bekerja lebih keras, karena proporsi yang didapatkan tetap yakni sebesar 20\%.Kondisi tersebut merupakan ciri dari sistem bagi hasil, seperti sistem bagi hasil di Ethiopia dimana petani penggarap (sharecropper) cenderung mengeluarkan curahan usaha dibawah curahan kerja optimalnya (Tran, 2016).

\section{EFISIENSI USAHATANI PADA MASING- MASING POLA PEMILIKAN LAHAN}

Sebelumnya telah dijelaskan bahwa sistem kedokan memiliki produksi paling rendah serta kecilnya proporsi bagi hasil menyebabkan pengedok menurunkan curahan kerjanya. Akan tetapi, fakta bahwa banyak pemilik lahan yang tetap memilih untuk mengedokkan lahannya membuat perlu dilakukan analisis pendapatan lebih mendalam. Pemilik lahan yang tidak mengelola sendiri lahannya memiliki dua pilihan yakni menyewakan atau mengedokkan lahannya. Ketika pemilik lahan memilih untuk menyewakan lahannya maka pendapatannya adalah biaya sewa lahan sementara apabila memilih mengedokkan lahan maka pendapatannya adalah $80 \%$ nilai produksi dikurangi biaya usahatani. Secara lebih rinci biaya usahatani masing-masing pola ditunjukkan pada Tabel 7 .

Pemilik lahan yang memilih untuk menyewakan lahannya akan mendapatkan pendapatan sebesar Rp 5.347.419/ha/musim sebagai pendapatan dari sewa lahan, sementara apabila memilih mengedokkan lahannya maka pendapatan yang diperoleh adalah $\mathrm{Rp}$ 9.933.737/ha/musim. Oleh karena itu meskipun produksi yang lebih rendah, pemilik lahan mendapatkan pendapatan yang lebih besar dengan mengedokkan lahannya dibandingkan dengan menyewakan lahan. Akan tetapi pada sistem kedokan, pemilik lahan harus menyediakan biaya usahatani dan menanggung risiko produksi Sementara kedua konsekuensi tersebut tidak harus ditanggung pemilik lahan apabila memilih untuk mengelola lahannya. Sehingga, apabila tidak ada batasan biaya (budget constraints) maka pemilik lahan akan memilih untuk mengedokkan lahannya. Kondisi tersebut secara umum sama di beberapa wilayah di Indonesia baik di Jawa maupun di luar Jawa dimana 
petani cenderung menyewakan lahan ketika memiliki kebutuhan ekonomi yang mendesak (Winarso, 2012).

TABEL 7 STRUKTUR BIAYA DAN PENERIMAAN USAHATANI BERDASARKAN POLA PEMILIKAN

\begin{tabular}{|c|c|c|c|}
\hline \multirow[b]{2}{*}{ Komponen } & \multicolumn{3}{|c|}{ Pola pemilikan } \\
\hline & $\begin{array}{c}\text { Milik } \\
\text { sendiri }\end{array}$ & Sewa & Kedokan \\
\hline \multicolumn{4}{|l|}{ Biaya Tetap } \\
\hline - Penyusutan (Rp) & 237.287 & 161.108 & 94.548 \\
\hline - Sewa Lahan (Rp) & - & 5.347 .419 & - \\
\hline - Pajak Lahan (Rp) & 236.292 & - & 100.774 \\
\hline $\begin{array}{l}\text { Total Biaya Tetap } \\
\text { (Rp/ha/musim) } \\
\text { Biaya Variabel }\end{array}$ & 475.578 & 5.598 .527 & 195.359 \\
\hline - Benih (Rp) & 738.336 & 690.812 & 492.732 \\
\hline - Pupuk (Rp) & 1.883 .905 & 1.620 .570 & 1.233 .577 \\
\hline - Pestisida (Rp) & 194.694 & 173.803 & 91.015 \\
\hline $\begin{array}{l}\text { - Tenaga Kerja Luar Keluarga } \\
\text { (Rp) }\end{array}$ & 3.034 .291 & 3.266 .759 & 1.028 .208 \\
\hline $\begin{array}{l}\text { - Sewa Traktor, Dores dan } \\
\text { Upah Pengairan (Rp) }\end{array}$ & 2.827 .012 & 2.866 .698 & 1.827 .691 \\
\hline $\begin{array}{l}\text { Total Biaya Variabel } \\
\text { (Rp/ha/musim) }\end{array}$ & 8.678 .238 & 8.618 .641 & 4.673 .223 \\
\hline Total Biaya (Rp/ha/musim) & 5.765 .950 & 14.217.169 & 4.868 .582 \\
\hline \multicolumn{4}{|l|}{ Penerimaan } \\
\hline - Produksi (ton/ha/musim) & 7,126 & 7,7 & 4,88 \\
\hline \multicolumn{4}{|l|}{ Proporsi Bagi Hasil } \\
\hline - Pemilik Lahan (kw) & - & - & \\
\hline - Petani Pengedok (kw) & - & - & 9,76 \\
\hline - Harga (Rp/kg) & 3.800 & 3.800 & 3.800 \\
\hline $\begin{array}{l}\text { Total Penerimaan } \\
\text { (Rp/ha/musim) }\end{array}$ & $\begin{array}{r}27.078 .80 \\
0\end{array}$ & 29.273.499 & 14.825 .703 \\
\hline Pendapatan (Rp/ha/musim) & $\begin{array}{r}21.312 .85 \\
0\end{array}$ & 15.056 .330 & 9.933 .737 \\
\hline Efisiensi Biaya & 4,696 & 2,059 & 3,045 \\
\hline
\end{tabular}

Selanjutnya perlu dilihat penerimaan dari sisi pengelola lahan, yakni petani lahan milik sendiri, penyewa, dan pengedok. Pendapatan petani lahan milik sendiri adalah $\mathrm{Rp}$ 17.925.216/ha/musim dengan nilai RC ratio sebesar 4,696. Sementara pendapatan petani penyewa adalah $\mathrm{Rp}$ 15.056.330/ha/musim dengan nilai RC ratio 2,059. Selanjutnya pendapatan pengedok adalah $\mathrm{Rp}$ 3.708.800/ha/musim, karena pengedok secara finansial tidak mengeluarkan biaya usahatani maka nilai RC ratio tidak bisa dikalkulasi. Hasil tersebut menunjukkan bahwa lahan merupakan faktor produksi utama dalam usahatani di Indonesia karena dengan jumlah luasan lahan yang dikelola sama, petani akan mendapat pendapatan tertinggi ketika mengelola lahan milik sendiri. Kondisi ini merefleksikan kondisi sosial yang ada pada masyarakat petani, dimana kepemilikan lahan merupakan ukuran utama status ekonomi. Selain itu dengan memiliki lahan sendiri, petani akan bisa mendapatkan manfaat ekonomi yang maksimal dari peningkatan aspek lain dalam usahatani seperti peningkatan produktivitas.

Selain didukung oleh hasil estimasi fungsi produksi sebelumnya, hasil penelitian ini juga didukung dengan data produktivitas usahatani padi pada masing-masing pola. Produktivitas pola milik sendiri, sewa, dan kedokan secara berturut-turut adalah 6,44 ton/ha, 7,37 ton/ha, 4,98 ton/ha. Perbedaan nilai produktivitas tersebut signifikan karena alokasi biaya usahatani untuk masing-masing pola pemilikan lahan cenderung sama (lihat Tabel 2). Berdasarkan wawancara yang dilakukan pada pemilik lahan kedokan dan pengedok, juga dapat diketahui bahwa melakukan sistem bagi hasil bukan merupakan keputusan paling optimal yang bisa mereka lakukan. Keputusan pemilik lahan untuk mengedokkan lahannya disebabkan karena tidak memiliki kesempatan untuk mengelola lahan sendiridan alasan kemanusiaan untuk membantu perekonomian pengedok. Alasan tersebut mengindikasikan bahwa apabila memiliki kesempatan maka pemilik lahan akan lebih memilih untuk mengelola lahannya sendiri. Sementara pengedok memilih untuk menggarap lahan kedokan sementara karenatidak memiliki modal untuk sewa lahan dan membiayai usahatani. Alasan lainnya adalah risiko mengedok lebih kecil dibandingkan dengan menyewa, mengedok bisa dikerjakan sebagai pekerjaan sampingan serta hasil dari kedokan bisa digunakan sebagai tabungan. Kondisi yang sama juga terjadi di Filipina, dimana pola pemilikan lahan berpengaruh signifikan terhadap efisiensi teknis usahatani dan lahan yang dikelola oleh penyewa memiliki produktivitas tertinggi, diikuti lahan milik sendiri dan yang terendah adalah lahan bagi hasil (Koirala et al., 2016).

\section{KESIMPULAN}

Hasil penelitian menunjukkan bahwa pola pemilikan lahan berpengaruh signifikan pada produksi usahatani padi, dimana lahan sewa memiliki produksi tertinggi, diikuti dengan lahan milik sendiri, dan yang paling rendah adalah pola lahan bagi hasil dengan sistem kedokan. Berdasarkan alokasi tenaga 
kerja, lahan milik sendiri menggunakan jumlah tenaga kerja terbanyak, diikuti dengan lahan sewa dan lahan bagi hasil menggunakan tenaga kerja paling sedikit. Sementara, lahan milik sendiri memiliki efisiensi biaya usahatani yang paling tinggi, diikuti dengan lahan bagi hasil kedokan dan yang memiliki efisiensi terendah adalah lahan sewa. Hasil penelitian ini menunjukkan bahwa dengan produksi yang rendah sistem bagi hasil merupakan keputusan ekonomi terbaik dari pemilik lahan dan juga petani penggarap. Selain itu, dengan sistem bagi hasil kedokan, pengedok bisa melakukan usahatani tanpa menanggung risiko produksi. Ahirnya, hasil penelitian ini juga mengkonfirmasi bahwa lahan merupakan aset terpenting bagi petani karena meskipun memiliki produktivitas rendah dibandingkan lahan sewa, lahan milik sendiri memiliki keuntungan lebih tinggi. Sehingga untuk meningkatkan kesejahteraan petani dalam jangka panjang, petani harus difasilitasi untuk memiliki lahan milik sendiri. Karena manfaat ekonomi dari peningkatan produktivitas usahatani tidak akan diperoleh secara maksimal oleh petani apabila petani tidak memiliki lahan sendiri.

\section{DAFTAR PUSTAKA}

Ash Shidiqie, J. S., \& Priyadi, U. (2015). Pelaksanaan Perjanjian Bagi Hasil Pertanian Lahan Sawah: Studi di Kecamatan Gamping, Kabupaten Sleman, Yogyakarta. Millah, 15(1), 101-115.

Asnawi, R. (2013). Analisis faktor-faktor yang mempengaruhi produksi padi sawah inbrida dan hibrida di Provinsi Lampung. Jurnal Sosial Ekonomi Pertanian Dan Agribisnis (SEPA), 1011), 11-18.

Badan Pusat Statistik. (2015). Analisis Rumah Tangga Usaha Tanaman Pangan di Indonesia. ( $\mathrm{H}$. Marhaeni, Ed.). Jakarta: Badan Pusat Statistik.

Bahasoan, H. (2011). Pola Penguasaan Lahan Pertanian dan Pengaruhnya Terhadap Kinerja Usahatani Padi Sawah di Kabupaten Buru. Media Trend, 6(1), 50-71.

Darwis, R. (2016). Sistem Bagi Hasil Pertanian Pada Masyarakat Petani Penggarap di Kabupaten Gorontalo: Perspektif Hukum Islam. A/Mizan, 12(1), 1-25.

Dupraz, P., \& Latruffe, L. (2015). Trends in family labour, hired labour and contract work on French field crop farms: The role of the Common Agricultural Policy. Food Policy, 51, 104-118.

https://doi.org/10.1016/j.foodpol.2015.01.003
Fauzi, N. F., Hariyati, Y., \& Aji, J. M. M. (2014). Sistem Tebasan Pada Usahatani Padi Dan Dampaknya Terhadap Kondisi Sosial Ekonomi Petani Di Kabupaten Jember. Jurnal IImiah INOVASI, 14(1), 26-34.

Hadiana, D. (2017). Analisis Efisiensi Faktor Produksi dan Pendapatan Usahatani Padi Sawah dengan Sistem Bagi Hasil (Suatu Kasus di Desa Kirisik Kecamatan Jatinunggal Kabupaten Sumedang). Jurnal IImu Pertanian Dan Peternakan, 5(2), 119-129.

Hayami, Y., \& Otsuka, K. (1993). The economics of contract choice: an agrarian perspective. Oxford: Clarendon Press.

Koirala, K. H., Mishra, A., \& Mohanty, S. (2016) Impact of land ownership on productivity and efficiency of rice farmers: The case of the Philippines. Land Use Policy, 50, 371-378. https://doi.org/10.1016/j.landusepol.2015.10 .001

Malik, M. K., Wahyuni, S., \& Widodo, J. (2018). Sistem Bagi Hasil Petani Penyakap Di Desa Krai Kecamatan Yosowilangun Kabupaten Lumajang. JURNAL PENDIDIKAN EKONOMI: Jurnal IImiah IImu Pendidikan, IImu Ekonomi Dan IImu Sosial, 12(1), 26. https://doi.org/10.19184/jpe.v12i1.6466

Manatar, M. P., Laoh, E. H., \& Mandei, J. R. (2017). Pengaruh Status Penguasaan Lahan Terhadap Pendapatan Petani Padi Di Desa Tumani, Kecamatan Maesaan, Kabupaten Minahasa Selatan. Agri-Sosio Ekonomi Unsrat, 13(1), 55-64.

Mubyarto. (2006). Pengantar Ekonomi Pertanian. Jakarta: Lembaga Penelitian, Pendidikan dan Penerangan Ekonomi dan Sosial.

Mudakir, B. (2011). Produktivitas Lahan Dan Distribusi Pendapatan Berdasarkan Status Penguasaan Lahan Pada Usahatani Padi (Kasus Di Kabupaten Kendal Propinsi Jawa Tengah). Jurnal Dinamika Ekonomi Pembangunan, 1(1), 74-83.

Neonbota, S. L., \& Kune, S. J. (2016). Faktor-Faktor Yang Mempengaruhi Usahatani Padi Sawah Di Desa Haekto Kecamatan Noemuti Timur. AGRIMOR: Jurnal Agribisnis Lahan Kering, 1(3), 32-35.

Onibala, A. G., Sondakh, M. L., Kaunang, R., \& Mandei, J. (2017). Analisis Faktor-Faktor Yang Mempengaruhi Produksi Padi Sawah Di Kelurahan Koya, Kecamatan Tondano Selatan. Agri-Sosio Ekonomi Unsrat, 13(2A), 237-242.

Setiawan, \& Kusrini, D. E. (2010). Ekonometrika. Yogyakarta: Andi.

Sihaloho, M., Purwandari, H., \& Mardiyaningsih, D. I. (2010). Reforma Agraria dan Revitalisasi 
Pertanian di Indonesia: Studi Kasus Pertanian Tanaman Pangan dan Hortikultura di Jawa Barat. Sodality: Jurnal Transdisiplin Sosiologi, Komunikasi Dan Ekologi Manusia, 04(01), 146-168.

Soekartawi. (1995). Analisis Usahatani. Jakarta: Penerbit Universitas Indonesia.

Sumantri, B., \& Fauzi, E. (2006). Analisa Produktivitas dan Pendapatan Usahatani Padi Sawah di Desa Lawang Agung Kecamatan Kedurang Kabupaten Bengkulu Selatan. AGRISEP, 4(1), 24-40.

Tran, A. N. (2016). Moral Hazard, Adverse Selection and Sharecropping in Ethiopia. In 5th International Conference of $A A A E$. Addis Ababa, Ethiopia 246972: African Association of Agricultural Economists (AAAE).

Wahyuningsih, T. (2010). Sistem Bagi Hasil Maro Sebagai Upaya Mewujudkan Solidaritas Masyarakat. Komunitas, 2(2), 94-105.

Winarso, B. (2012). Dinamika Pola Penguasaan Lahan Sawah di Wilayah Pedesaan di Indonesia. Jurnal Penelitian Pertanian Terapan, 12(3), 137-149.

Yuliana, Ekowati, T., \& Handayani, M. (2017). Efisiensi Alokasi Penggunaan Faktor Produksi Pada Usahatani Padi di Kecamatan Wirosari Kabupaten Grobogan. AGRARIS: Journal of Agribusiness and Rural Development Research, 3(1), 39-47. https://doi.org/10.18196/agr.3143 